\title{
Determinants of consumer purchasing decision in the e-commerce sector in Poland - generation perspective
}

\author{
Olga Dębicka ${ }^{1, *}$ Tomasz Gutowski ${ }^{1}$, and Adam Borodo ${ }^{1}$ \\ ${ }^{1}$ University of Gdańsk, Faculty of Economics, 119/121 Armii Krajowej, 81-824 Sopot, Poland
}

\begin{abstract}
Development of the e-commerce sector in Poland over the last decade has been extremely dynamic. Both its value and share in GDP have increased, and the growth rate of on-line retail sales in Poland is currently one of the highest in Europe. The market development is driven either by changes in the behavior of consumers who are increasingly shopping online, as well as by growing number of e-stores. The main objective of this article is to identify the key factors determining purchasing decisions in the ecommerce sector in Poland by assessing the impact of differences in the characteristics of generations on their preferences regarding e-commerce. Each generation is significantly different from each other in terms of work, education, security, success in professional and personal life, as well as in terms of consumption. The characteristics of individual generations and the level of their digital competence have a significant impact on the way in which a given generation makes purchases and what is expected in the purchasing process. In order to establish the key determinants of on-line purchasing decision, a method of on-line survey was used. The quota sample included three generations of Polish Internet users: 260 people at the age between 25-37 (generation Y); 200 people at the ages between 38-50 (Generation X) and 100 people at the age between 51-70 (baby boomers generation). The structure of the article includes a presentation of the problem against the background of relevant literature, theoretical assumptions of the research, its findings, discussion and conclusions.
\end{abstract}

\section{Introduction}

Over the years we have been observing the dynamic development of the e-commerce market. Both technological development and increasing number of Internet users contribute to this growth. Promotional activities undertaken by e-shops are not without significance. Only a few years ago e-shopping was a curiosity rather than everyday life, and market share of online shopping was negligible. Internet users approached e-shopping with distrust typical for all kinds of innovations. Such attitude is hardly surprising, especially when taking rather limited knowledge of the mechanisms governing this specific type of sales into account. The last decade however has brought surprising changes when it comes to the e-commerce market.

\footnotetext{
*Corresponding author: olga.debicka@,gmail.com
} 
While in 2006 there were only 2,800 online stores operating on the Polish market, currently it is estimated that the number of online stores may vary between 15,000 and even $20,000[1,2]$. Today, there are tens of thousands of e-stores in Poland that offer virtually everything in their assortment, and more than half (55\%) of Polish internet users declare the use of online shopping [1]. Considering the value of e-commerce, in 2006 it amounted to PLN 8.1 billion, and in 2017 it reached PLN 36-40 billion [1, 2]. However, there are some symptoms of gradual flattening of growth dynamics, and the market is moving from the "evolution" phase (growth over 20\%) to the "stabilization" phase (annual increases below $20 \%$ ). Slower growth is primarily the effect of gradually reaching market maturity.

Analysts estimate that the e-commerce market in Poland, when it comes to the number of online stores, already shows some saturation. And even though as many as $78 \%$ of online stores in Poland achieved sales growth in 2017, about 8,000 new online stores are falling every year. Moreover, as many as $80 \%$ of newly established enterprises engaged in Internet commerce fall within 3 years of activity. In the majority of cases, these are small and medium enterprises with very little experience and knowledge in the scope of electronic commerce. What is more, according to experts, these companies focus too much on marketing and acquiring new customers, forgetting about previously acquired customers [3]

And although the chances to change such state of affairs can be seen in innovations, new technologies, or especially in artificial intelligence, the basic problem is understanding and meeting the expectations of various customer groups.

It is worth emphasizing that in many aspects one can notice the differences between consumers resulting not only from their gender, place of residence or income they earn, but also from their age. Understanding the characteristics of individual generations of consumers and factors influencing their purchasing decisions will allow to understand their expectations and meet their requirements, by adjusting online stores and skillful use of new technologies. Knowledge of these factors also allows entrepreneurs to define the strategy of developing an online store, as well as increasing the company's competitiveness on the market by introducing changes and facilities for customers.

\section{Determinants of e-shopping-theoretical framework and literature review}

Already in the beginning of XXI century, Shiu and Dowson predicted that with gaining expertise in Internet use, even other than shopping, the consumers use of electronic shopping opportunities was expected to increase $[4,5]$, influencing the shape of business models [6] and the profitability of individual industries. So as identification of the factors determining online shopping decisions has become an interesting and important research issue, extensively discussed in the literature on the subject in the past two decades.

Surveys of consumer behavior were made both from consumer and technology oriented perspectives (Table 1.).

Stanshevsky and Liebermann found that in environments where e-commerce has yet to mature, the task of predicting online shopping behaviour is more complicated and challenging, pointed that in the early stage of on-line market many studies focused on examining the likelihood of online buying from the perspective of weighting its benefits against its costs [7]. This approach, represented in studies of Teo and $\mathrm{Yu}$ [8], Chwelos et al. [9], Bhatnagar and Ghose [10], Alreck and Settle [11], Forsythe and Shi [12] basically aggregated these determinants in groups of financial and non-financial nature. Product and delivery prices were the two main economic factors stressed by many authors [as basic economic factors conducive to making online purchases. The money saving was also 
mentioned as the main advantage of e-commerce by consumers in Poland. According to Jasiński [13], consumers looking for lower prices were supposed to be the main drivers of the growth of the e-commerce market at that time.

Table 1. Surveys of consumer behavior.

\begin{tabular}{|c|c|c|}
\hline Perspective & Influencing factors & Authors \\
\hline \multirow{6}{*}{ Technology } & $\begin{array}{l}\text { technical specifications } \\
\text { of an online store }\end{array}$ & (Zhou et al., 2007) \\
\hline & $\begin{array}{l}\text { interface, design and } \\
\text { navigation }\end{array}$ & (Zhang and Von Dran, 2002) \\
\hline & payment & $\begin{array}{l}\text { (Torksadeth and Dhillon, 2002; Liao and Cheung, } \\
\text { 2002) }\end{array}$ \\
\hline & information & (Palmer, 2002; McKinney et al., 2002); \\
\hline & intention to use & (Chen and Hitt, 2002); \\
\hline & ease of use & (Devaraj et al., 2002; Stern and Stafford, 2006). \\
\hline \multirow{5}{*}{$\begin{array}{l}\text { Consumer } \\
\text { oriented }\end{array}$} & $\begin{array}{l}\text { psychological } \\
\text { characteristics }\end{array}$ & $\begin{array}{l}\text { Hoffman and Novak 1996; Lynch and Beck 2001; } \\
\text { Novak et al., 2000; Wolfinbarger and Gilly 2002; Xia } \\
2002\end{array}$ \\
\hline & demographics & (Brown et al., 2003; Korgaonkar and Wolin, 1999), \\
\hline & $\begin{array}{l}\text { perceptions of risks and } \\
\text { benefits }\end{array}$ & $\begin{array}{l}\text { (Bhatnagar } \\
\text { and Ghose 2004; Huang et al., 2004; Kolsaker et al., } \\
\text { 2004;), }\end{array}$ \\
\hline & shopping motivation & $\begin{array}{l}\text { (Childers et al. } \\
\text { 2001; Johnson et al. 2007; Wolfinbarger and Gilly } \\
\text { 2002), }\end{array}$ \\
\hline & shopping orientation & $\begin{array}{l}\text { (Jayawardhena et al., 2007; Swaminathan et al., } \\
\text { 1999). }\end{array}$ \\
\hline
\end{tabular}

On the other hand, as the experience of consumers in the early stages of the development of e-commerce has been not large, McKnight and Chervany [14] pointed that wherever risk, uncertainty, or interdependence exist it is trust that is crucial to interpersonal and commercial relationships. Yang and Jun [15] emphasized the important role of such factors that increase trust in the transaction as reliability, access and ease of use. Another group of principal perceived benefit referred to convenience of use. Wolfinbarger and Gilly [16] particularly distinguish such aspects as selection and information availability in that group while Brown focuses on aspects related to service quality.

With time passing, and the growing market share of e-commerce, the online consumer behavior has been analyzed from the perspective of many disciplines, such as information systems, marketing, management science, psychology and social psychology, classifying main factors determining on-line shopping into a number of categories, including economic, organizational, legal, security, socio-psychological, technical and technological factors [17]. Some of research started to focus on forming the basis for creating a typology for a given population. In the A Typology of Online Shoppers Based on Shopping Motivations Rohm and Swaminathan suggest the existence of four shopping types: convenience shoppers, variety seekers, balanced buyers and store-oriented shoppers [18]. Jaciow and Wolny, in a comprehensive study on typology of Polish e-consumers described four types of the Polish e-client: a type that saves money when shopping, a type looking for the highest quality products, a type devoting as little as possible to shopping and a type that takes pleasure in shopping [19]. Consumer attitudes towards e-shopping have been most recently examined a priori in developing such models using four consumer traits: gender, education, income and age [20]. The last trait is recently gaining more attention, as many of the factors either from 
costumer-oriented perspective and the technological approach are resulting from belongings to particular generations.

\section{Characteristic of generations in Poland and their behavior on the Internet}

Electronic commerce must constantly evolve to adapt to changing realities and to meet the expectations of different consumer groups. It is extremely important to know the characteristics of different generations of buyers. Understanding their values, goals, motivations or approaches to shopping and the skillful use of this knowledge determines the effectiveness of trade and the position of the company on the market. The insights and applications that flow from robust generational analysis is of great value to the development of e-commerce strategies and models.

Every generation is markedly different in the issues of work, education, safety, success in professional and personal life, as well as in the matter of the consumption. The characteristics of individual generations and the level of their digital competence have a very significant influence on the way into which a given generation is making purchases and what it expects in the process.

According to William Strauss and Neil Howe a generation refers to a cohort of people born within a similar span of time [21]. Social sciences agree that all its members should combine a certain characteristic bond, a community of values and beliefs.

There are 6 defined generations living now in the modern world and differences between them are an inseparable part of every life. In his research McCrindle clearly emphasizes the fact that there are very real differences between the life experiences of the generations, especially over the latter decades of the 20th century [22]. In addition to a different view of the world, behavior, differences in expectations regarding the career path or decision-making, including purchasing processes, are becoming more and more noticeable. It is the result of the constantly changing environment and lifestyle, the development of science and the advances in technology.

In contemporary literature there are more and more studies on differences between generations in Poland, but the most current and most common is the division into 5 groups: traditionalists, baby boomers and XYZ generations.

The generation of traditionalists, also known as builders or maturists, born in between 1924 - 1945, coming of age during the postwar happiness, can be considered the oldest generation of Internet users. They are characterized by a large attachment to tradition and a great reluctance, and even fear of any change. For this generation, the most important values in life are: hard work, sense of duty, dedication, respect for authorities. They attach great importance to authorities. Currently, it is the oldest generation, still professionally active [23].

The generation of traditionalists is the least numerous group of people using the Internet in Poland ( $(23 \%)$, and the majority of Polish studies do not take this age group into account due to their negligible size. This group is the one most affected by digital exclusion. The main reasons for staying in the off-line sphere are: lack of skills and no need to use the Internet, as well as high costs of equipment and access to the network.

The next cohort is the generation of people born in 1946-1964, the so called baby boomers, for whom it is important to achieve success. (47\%). Solidarity and loyalty are important values for them, but they have also gained a few other characteristics resulting from growing up in the communist system in Poland. These include, among others, distrust and even suspicion towards other people and their intentions, a claiming attitude, difficulty in adopting a civic attitude, and the desire to eliminate uniqueness and pugnacity in the name 
of safe mediocrity [16]. People who belong to this generation grew up in difficult conditions, which is why the greatest value for them is safety and stability. According to CBOS "Internet users 2017" research, over the past five years, the percentage of people using the Web from the late baby boomers cohort (55-64 years) has increased by 17 percentage points to $47 \%$. A similar increase took place in the age group of 65 and more, from 9\% in 2011 to $23 \%$ in 2017 [24]. This is probably caused by slow inflow of older representatives of next generation to this cohort with each subsequent year.

People who belong to the generation of baby boomers, despite the difficulties they encounter in the use of new technologies, try to resist digital exclusion. However, they use the Internet and mobile applications relatively least frequently. According to the latest CBOS research, baby boomers spend on average over 9 hours a week on the Net. These are mainly sports and business websites as well as applications for communication with loved ones.

First of the young generations is the so-called $\mathrm{X}$ generation which includes people born in the second half of sixties up to the eighties of the 20th century. Those are the people born in the days of the cold war, but also a sexual revolution which shook the conservatism and the traditionalism of the previous generations. They were brought up in the days of the first computers, mobile phones and technological gadgets. For the $\mathrm{X}$ generation the work-life is important. People belonging to this generation value the work, especially since they were brought up by previous generations which had fulfilled their needs thanks to it. In years in when they grew up soft competence gained more meaning, therefore they are so interested in the development of their own abilities and improving oneself. People of the $\mathrm{X}$ generation are using the Internet far more than the older generations. On average about the $73 \%$ of people included in the $\mathrm{X}$ generation use the Internet, and the time they spend on browsing amounts to about 10 hours every week. It is important to add that over $76 \%$ of Internet users of this generation go online wirelessly via mobile devices such as the laptop computer, mobile phone or tablet.

The activity of this group on the Internet is growing constantly, however people belonging to the $\mathrm{X}$ generation relatively rarely use mobile applications and use them in smaller volumes in comparison to the younger generations. As in case of the baby boomers generation, representatives of the $\mathrm{X}$ generation are choosing messengers used for conversations and supporting the relations with family and friends and applications designed for the purposes of online shopping and cataloguing photographs. Sites they visit which are most often about business and finance, the real estate, sports and everyday events [23].

A next one is generation $\mathrm{Y}$ which until recently was still regarded as the youngest. It is also called the "Millennials", "next generation", "digital generation" and "generation of flaps and iPods". There are no precise dates when the generation starts and ends. Researchers and commentators use birth years ranging from the early 1980s to the early 2000s [18]. Millennial young people are well educated, self-confident, self-supporting and independent. It is a generation which is committed to its work and its values, however it is treated equally with fun, social life or leisure time. The millenials is a group, in which $95 \%$ of people use the Internet, with the average time spent by them online amounts up to 18 hours every week. These numbers are constantly rising, with the biggest noticeable increase in the number of users of social networking sites. In 2011 this percentage amounted to the $68 \%$, whereas in 2017 it grew up to $96 \%$ [24]. Representatives of this generation have the strongest spending validity in the world and it is forecasted, that until 2020 the Millenials expenses will constitute one third of all expenses in retail shops [23]. At present times the expenses of this group made on the Internet are bigger than of any other age group and are on average 2000 dollars annually. Most willingly they use social networking applications and applications which function as online data storage, maps or advertising services. The websites which make them most involved are the ones about jobs, professional career, construction and real estate [23]. 
There is a different characteristics that can be attached to a younger generation generation Z. Those are people born at the end of the 1990s. They are 20-year-olds and younger, who are at the beginning of their adult lives. As the research conducted by Urszula Płosarek shows [25], the indicator of success in life for the $Z$ generation is personal satisfaction, being a professional, an expert in a given field and the possibility of expressing oneself through work. Representatives of the $\mathrm{Z}$ generation are mostly people financially supported by their parents so they do not have to worry about money. They are people who are just entering adult life, learning, beginning studies, and few are taking their first steps on the job market. These people grew up in a world full of electronics, advanced devices also available at present such as notebooks, tablets or iPods. Majority of representatives of the $\mathrm{Z}$ generation have outstanding computer skills, as well as the ability to multitask. They are acquiring information and knowledge mainly from the network. The major advantage of the $\mathrm{Z}$ generation is the speed with which they assimilate knowledge, particularly the one associated with electronics and innovations. Generation $\mathrm{Z}$ is an age group with the highest digital competence at present, $97 \%$ from are Internet users. They spend 17 hours on average every week browsing the net, what compared with results from 2011 is 3 hours more. In this age group the number of Internet users as well as social networking sites is growing year to year. According to research the percentage of people using social networking sites has risen by 10 percentage points within five years and at present amounts to $92 \%$ [24].

Despite the low purchasing power caused by low earnings people from the $\mathrm{Z}$ generation spend the largest percentage, which is as far as $9 \%$ on the Internet. We can assume that within years and a rise in earnings of this group, its expenses will become one of crucial growth factors of the e-commerce.

The $\mathrm{Z}$ Generation is far different from the Millenials. They are much more involved in using Snapchat and musical.ly, which helps them communicate with peers in a creative way with short video recordings and other functional applications apart from Facebook. They are interested in services about educational, technological and cultural-light subject matters [23].

The presented characterizations of individual generations show that the time in which a given generation is brought up has a very significant influence on its view of the world, motivations, goals and values in life. Because of the technological development, despite small age differences even the closest age groups are markedly different. Therefore the entrepreneurs have a difficult task, on the one hand they should adjust to an ageing consumer society, on the other they must meet high expectations of the younger generations.

\section{Research methodology and population sample}

The main objective of this article is to identify the factors which have a positive and a negative impact on the use of opportunities created by e-commerce on the representatives of each generation.

The study of purchase preferences was carried out with the help of CAWI (ComputerAssisted Web Interview) dynamic questionnaire forms. The data was collected between 02.07 - 30.07 2018. Interviews from 560 people were analysed. The quota sample included 3 generations of Polish Internet users: 260 people aged 25-37 (generation Y); 200 people aged 38-50 (Generation $\mathrm{X}$ ) and 100 people aged 51-70 (the baby boomers generation). In the section of $25-37$ years there were $50,8 \%$ women and $49,2 \%$ men. In the section of $38-50$ years there were $46 \%$ women and $54 \%$ men. In the oldest age group (51-70) the 56\% majority were women, and $44 \%$ were men. In order to guarantee high quality of data, only fully finished surveys were included in the analysis. 


\section{Analysis of the findings and discussion}

People aged from 25 to 37 years were the most numerous group of the examination. The majority $(58,5 \%)$ in this group were people with higher education, most of the respondents were women $(51 \%)$. In the group of respondents at the age of 38-50there were slightly more women. The respondents were mostly people with secondary or higher education.

We may notice standard behavior of recipients who declare that they make online purchases up to two or three times a week, finishing at a few times per half a year. The result of $73 \%$ of the examined group in the scale of $54 \%$ of the entire country is a result confirming involvement of this section in the shopping with the use of the electronic channel. Such commitment has an impact on distinguishing the determining factors on the choice of the Internet for shopping. At the age of 38-50 over $40 \%$ does online shopping very rarely or never. The result is also interesting especially taking other results of shopping research into account.

Groups of people who make purchases once every half year or once a month make another $42 \%$ of respondents. The results clearly show that people born between 1968-1980 do not constitute the main group of online buyers. Formation of their shopping habits and the beginning of their professional careers came at the beginning of the XXI century, when online shopping possibilities were still largely limited. Comparing the results with respondents aged 50 or more, the percentage of those interested in online shopping is high. It's worth reminding that the auction site Allegro.pl entered the Polish market in 1999, and after a few years it had more than 60 thousand active users. Surely, among other reasons why there is less online shopping in this group we can point out that there was less Internet in the past, there are limitations concerning security of online shopping and that the competition in the virtual market is small. The answers to the question about reasons for online shopping do not come as a surprise. In each of the analysed age groups the most motivating factor is the lower price than in traditional shopping. This forms $90 \%$ of the responses received.

Analysing the results of the two oldest groups, we can assume that they are based on the fact that people at this age attach importance to their financial resources, wanting to save money while shopping. One interesting result in this age group is the negligible interest in the quality of the service. Only $4 \%$ of respondents paid any attention to that part of online shopping, for majority of respondents this is irrelevant. Apart from the price, another argument supporting online transactions is the convenience while shopping without leaving home. It is an important factor for $68 \%$ of the group. Among the first three main categories of online purchases the first one are cinema or theatre tickets. It is important for $36 \%$, while for the older groups accordingly $40 \%$ and $44 \%$. Books, CDs and DVDs are the second most mentioned category, pointed by $32,5 \%$ of the youngest, $16,3 \%$ of the older and $12 \%$ of the oldest generation. The third important element for almost $32,5 \%$ are clothes and accessories, for the age groups of 50 and 70 it is $40 \%$ and $38 \%$. The differences between the researched groups are small, although it is said that the younger generation is more indifferent. In this group the online shopping websites are of most importance for $34 \%$, and online shops without auctions for $36 \%$. The answers to the question about the kinds of online shops used, the respondents at ages between 31-50 show that they prefer shopping at commonly known places. They generally do not use online auction sites. We can even risk saying that the purchased goods are not extraordinary. The common use of the Internet in everyday life of the youngest group of respondents is also present when we talk about the device which is used for online shopping. The smartphone is the main device for almost $40 \%$, which is higher than a laptop computer or a notebook declared by $32 \%$. The device most commonly used for gathering information about offered online stock for people at the age between 38-50 are the personal computer and laptop computer or the notebook. Smartphones and tablets are less commonly used. The use of the newest means making online shopping possible may come 
from the lack of those devices in this age group. The attachment to previously older and better known devices seems the most important. The same results concern the very act of purchase on the Internet. In this case the most common device is the personal computer or laptop computer/notebook.

What came as a surprise in this age group are the answers about making decisions about purchases with the use of social media, about $9,5 \%$ of the respondents claimed that they have made a purchase on social networking sites. The 25-37 age group is the one spending most time browsing social media. In this group Facebook is most common for $70 \%$, the second one is YouTube with $63 \%$. It seems that the choice of the shopping platform is influenced by remarketing used in business channels of Facebook, YouTube or other social networking site.

In the 38-50 age group the majority are people who pay for the purchased goods online. Minority being the ones using mobile payments, about one in ten respondents. Perhaps this is caused by lack of knowledge about the newest forms of making payments or lack of trust for such advancements.

Another important features of online shopping for 31\% of respondents were lack of queues, extended information given about the product and loyalty programs. What is important for other people who took part in the research is least important for the mentioned group - making purchases in a real shop or with the help of an assistant in eg. a department store. $37 \%$ of them gave a negative response to this question. The last part which connects all three researched groups is the positive answer to the question if e-commerce is innovative, $81 \%$ for the $27-37$ group, $66 \%$ for the $38-50$ group and $56 \%$ for the $51-70$ group. For both the over 50-year-olds and 38-50 one of the biggest disadvantages of online shopping is the lack of possibility to touch and see the chosen products. In both researched groups $30 \%$ of respondents complained about this part of online shopping. A bigger "threat" is the risk of getting a faulty product or a product not fitting the description. In both groups the percentage answering this question is the highest. This concern is the highest in the oldest (over 50 years) group, over $36 \%$. This may mean that there is a low level of trust towards the people selling things online, which probably comes from the habit of buying things in a traditional way. Among other advantages of online shopping the respondents point to the possibility to make the transaction without leaving their homes. Same results are also given in the age groups below 38 and over 50.

\section{Conclusions}

Online purchase decisions are determined by a lot of factors, which among others include the age of customers, their knowledge about modern technologies and often their long-term habits. Directing a scientific discussion about who and why is making or not making online purchases seems to be an extremely important issue. Overwhelming modern technology and possibilities created by it, make customers interest in online shopping even greater. It is difficult to make a firm statement about what the future customers and salesmen market will be like. However, it is certain that it is in transitional phase at present. In a few years the number of online transactions will multiply, which will lead to necessary changes in the ways of traditional sales. 


\section{References}

1. Internet Standard, E-commerce Standard 2017, Internet Standard, Warszawa 2018, https://www.internetstandard.pl/whitepaper/2935-E-commerce-Standard-2017.html (2017)

2. O. Dębicka, Economics of the 21st Century, 3 (11), 335-345 (2016) http://www.dbc.wroc.pl/dlibra/docmetadata? $\mathrm{id}=36229 \&$ from=publication

3. O. Dębicka, A. Borodo, J. Winiarski, Zeszyty Naukowe Uniwersytetu Gdańskiego. Studia i Materiały Instytutu Transportu i Handlu Morskiego, 14, 145-157 (2017), http://studiaimaterialy.pl/artykul/2018/ochrona-danych-osobowych-wbranz $\% \mathrm{CC} \% 87$ y-e-commerce-w-polsce/

4. E.C.C Shiu, J. Dawson, The Service Industries Journal, 22(1), 147-166 (2002)

5. A.V. Citrin, D.E. Sprott, S.N. Silverman, D.E. Stem, Industrial Management \& Data Systems, 100(7), 294-300 (2000)

6. D. Chaffey, Digital Business and E-Commerce Management. Strategy, Implementation and Practice (Wydawnictwo Naukowe PWN, Warsaw, 2016)

7. Y. Liebermann, S. Stashevsky, Canadian Journal of Administrative Sciences, 26, 316 331 (2009)

8. T.S.H. Teo, Y. Yu, Omega, 33(5), 451-465 (2005)

9. P. Chwelos, I. Benbasat, A.S. Dexter, Information Systems Research, 12(3), 304-321 (2001)

10. A. Bhatnagar, S. Ghose, Journal of Business Research, 57(12), 1352-1360 (2004)

11. P. Alreck, R.B. Settle, Journal of Database Marketing, 9(2), 150-162 (2002)

12. S.M. Forsythe, B. Shi, Journal of Business Research, 56(11), 867-875 (2003)

13. J. Jasiński, Wybór celu, modelu i strategii [in:] B. Gancarz-Wójcicka, Biblia e-biznesu (Helion, Gliwice, 2013)

14. D. Harrison McKnight, L. Norman-Chervany, Proceedings of the 34th Hawaii International Conference (2001)

15. The E-Commerce Book, Building the E-Empire (Communications, Networking and Multimedia) (Academic Press, San Diego)

16. Z. Yang, M. Jun, Journal of Business Strategies, 19 (1), 19-41 (2002)

17. M. Wolfinbarger, M.C. Gilly, California Management Review, 43 (2), 34-55 (2001), http://j.pelet.free.fr/publications/comparaison_brick_\%26_mortar_ecommerce/Shoppi ng_online_for_freedom_control_and_fun_WOLFINBARGER.pdf

18. T. Parys, W. Chmielarz, Procedings of 5th International Conference on Seviceology, Publisher: Vienna University, Editors: D. Bork, E.-T. Miron

19. A. Rohm, V. Swaminathan, Journal of Business Research 57 (7), 748-747 (2004) https://www.sciencedirect.com/science/article/abs/pii/S014829630200351X

20. M Jaciow, R. Wolny, Polski e-konsument Typologia, Zachowania (Wydawnictwo Helion, Gliwice, 2011)

21. C. Dennis, B. Merrilees, Ch. Jayawardhena, L.T. Wright, European Journal of Marketing, Vol. 43 Issue: 9/10, 1121 - 1139 (2009) https://www.emeraldinsight.com/doi/abs/10.1108/03090560910976393

22. W. Strauss, N. Howe, Millennials Rising: The Next Great Generation (Vintage, USA, 2000) 
23. M. McCrindle, The ABC of XYZ. Understanding the global generations (A McCrindle Publication, Bella Vista NSW 2153, 2014)

24. A. Miotk, Generacje w Internecie, Polskie Badanie Internetu, Warszawa, http://pbi.org.pl/wp-content/uploads/2017/10/Generacje-w-internecie.pdf dostęp: 18.02.2018 (2017)

25. M. Feliksiak, Korzystanie z Internetu, [in:] Komunikat z badań nr 47/2017 (Centrum Badań Opinii Społecznej, Warszawa, 2017) 